\title{
FAKTOR YANG MEMPENGARUHI TINDAKAN LANSIA DALAM PENCEGAHAN COVID 19
}

\author{
Ezalina1, Deswindaㄹ, Fitry Erlin ${ }^{3}$ \\ Email : ezalin44@gmail.com \\ 1,2,3Program Studi S1 Keperawatan, Stikes Payung Negeri Pekanbaru Indonesia
}

\begin{abstract}
More than 95\% of deaths due to Covid-19 are in the elderly. The existence of physical distancing makes the elderly stay at home more so that they can survive from Covid-19 pandemic situation, yet in another side they must keep doing physical and social activities. This study aimed to determine the most influencing factors of their actions in preventing Covid-19. A quantitative study using an analytical observational method with a cross-sectional design was done in RW 10 LabuhBaru Barat, Payung Sekaki Subdistrict in October 2020. 104 elderly people were taken as samples by using purposive random sampling. Pearson Chi Square test was used to assess the relationship between actions and age, gender, education, knowledge, and attitude. Then, each independent variable was tested using logistic regression analysis to determine the most influential variable. The result of this study indicated that there were effects of age $(p=0.000) ;$ gender $(p=0.000)$; education ( $p=0.000) ;$ knowledge $(p=0.000) ;$ and attitude $(0.006)$ towards the actions of the elderly in preventing Covid-19. Then, the result of logistic regression test showed that knowledge became the most influencing variable towards the action of the elderly in preventing of Covid-19 (OR=39.36), meaning that elderly people with high knowledge took Covid-19 preventive action by 39.36 times compared to those with low knowledge. Therefore, it is necessary to give them knowledge about the prevention of Covid-19 by obeying health protocols so that the elderly can remain active and productive in life.
\end{abstract}

\section{ABSTRAK}

Lebih dari 95\% kematian akibat Covid 19 terdapat pada lansia. Adanya phisical distancing menyebabkan lansia lebih banyak berada di rumah agar dapat bertahan dalam situasi pandemi Covid 19 padahal lansia harus tetap melakukan aktifitas fisik dan aktifitas sosial. Penelitian ini dilakukan untuk mengetahui faktor-faktor yang paling mempengaruhi tindakan lansia dalam pencegahan Covid 19. Penelitian kuantitatif menggunakan metode observasional analitik dengan rancangan cross-sectional dilakukan di RW 10 Kelurahan Labuh Baru Barat Kecamatan Payung sekaki pada bulan Oktober 2020. Penentuan teknik pengambilan sampel menggunakan purposive random sampling dengan jumlah sampel 104 orang lansia.Uji pearson chi square dilakukan untuk menilai hubungan antara tindakan dengan usia, jenis kelamin, pendidikan, pengetahuan dan sikap. Masing-masing variabel independen di evaluasi menggunakan analisis uji regresi logistik untuk menetukan variabel yang yang paling berpengaruh. Hasil penelitian ini menunjukkan bahwa ada pengaruh usia $(p=0.000)$; jenis kelamin $(\mathrm{p}=0.000)$; pendidikan $(\mathrm{p}=0.000)$; pengetahuan $(\mathrm{p}=0.000)$; sikap $(0.006)$ terhadap tindakan lansia dalam pencegahan Covid 19. Dari hasil uji regresi logistic menunjukkan variabel pengetahuan yang paling berpengaruh terhadap tindakan pencegahan Covid $19 \quad(\mathrm{OR}=39.36)$ yang artinya lansia yang berpengetahuan tinggi akan melakukan tindakan pencegahan Covid 19 sebesar 39.36 kali dibandingkan lansia yang mempunyai pengetahuan rendah. Oleh karena itu kepada lansia perlu diberikan pengetahuan tentang pencegahan Covid 19 dengan mematuhi protokol kesehatan sehingga lansia tetap bisa aktif dan produktif dalam menjalani kehidupan.

\section{ARTICLE INFO}

Keywords:

Elderly; Covid 19; Preventive action

DOI:

10.24252/kesehatan.v14i2.21168

Kata kunci :

Lansia; Covid 19; Tindakan Pencegahan

\section{Pendahuluan}

Covid 19 merupakan ancaman masyarakat global yang menciptakan situasi pandemi di seluruh dunia. Menanggapi hal ini Badan Kesehatan Dunia atau WHO (Word Health Organisation) mendeklarasikan sebagai Public Health Emergency of International Concern (PHEIC) sebagai kedaruratan kesehatan masyarakat yang meresahkan dunia (1). Jika dilihat dari segi umur tingkat kematian paling tinggi banyak terjadi pada lansia. Menurut WHO lebih dari 95\% kematian terjadi pada usia 60 tahun atau lebih dan lebih dari 50\% kasus kematian terjadi pada usia 80 tahun keatas. Pandemi Covid 19 menunjukkan jumlah kasus dan risiko yang besar seiring dengan bertambahnya usia (2). Hasil penelitian menunjukkan adanya tingkat kerentanan yang tinggi terhadap infeksi seiring dengan bertambahnya usia. Kerentanan lansia 
akibat Covid 19 dapat dilihat dari data statistik lansia pada beberapa negara. Di Malaysia data lansia meninggal akibat Covid 19 62,6\%, Brazil 85\%, Italia 95\%, Spanyol 95,5\%, Tiongkok 80\%, dan Amerika Serikat 80\% (3), sedangkan Indonesia jumlah kematian pada lansia sebesar 43,7\% (4).

Ageing population yang sedang dihadapi Indonesia ditandai dengan presentase lansia yang mencapai 10\% pada tahun 2020 (5). Negara yang mengalami penuaan penduduk cenderung memiliki risiko penyebaran virus yang relatif cepat dan angka kematian yang tinggi. Studi terhadap beberapa pasien Covid 19 di China menunjukkan fakta bahwa tingkat risiko penularan dan kematian (fatality rates) pada pasien lansia lebih tinggi dibandingkan pasien pada katagori muda (Liu K. Hal ini artinya dengan bertambahnya usia berpengaruh secara signifikan terhadap risiko kematian. Penyakit penyerta yang dialami lansia seperti penyakit cardiovaskuler, hipertensi, diabetes mellitus, asma, membuat tingkat infeksi pasien Covid 19 menjadi lebih berat.

Adanya penerapan pembatasan phisical distancing dalam pencegahan Covid 19 dan meningkatnya risiko kematian akibat Covid 19 pada lansia menyebabkan lansia lebih banyak berada di rumah yang berdampak pada kendala komunikasi dalam menyampaikan keluhan penyakit akibat terbatasnya aktifitas sosial dan aktifitas fisik pada lansia (6). Berlakunya era tatanan kehidupan normal baru yang juga dihadapi oleh para lansia, lansia harus mendapat akses dalam hal edukasi dan pendampingan untuk meyesuaikan diri dengan perubahan new normal. Oleh sebab itu agar lansia dapat bertahan dalam situasi pandemi Covid 19 perlu diketahui tindakan yang dilakukan lansia dalam pencegahan Covid 19.

Perubahan tatanan kehidupan selama masa pandemi Covid 19 merupakan suatu tantangan untuk melakukan suatu perubahan perilaku dalam tindakan pencegahan Covid 19 (7). Kepatuhan untuk melakukan tindakan pencegahan melalui pelaksanaan protokol kesehatan dapat memutus rantai penularan dan menekan angka penyebaran Covid 19. Hasil Survei BPS selama tanggal 7-14 September 2020 menunjukkan masih adanya 17\% responden yang yakin atau sangat yakin diri mereka tidak tertular Covid 19 sehingga bisa berdampak terhadap pengabaian dalam tindakan pencegahan Covid 19 (8).

Hasil penelitian Setyaningsih (2020) tentang perilaku lansia dalam tindakan pencegahan Covid 19 didapatkan hasil cukup dengan presentase 53,2\%. Penelitian (9) tentang melaksanakan protokol kesehatan selama Covid 19 didapatkan kebisaan mencuci tangan 67\%, memakai masker 76\%, dan menjaga jarak 70\%. Sedangkan hasil penelitian (10) kekhawatiran lansia tentang Covid 19 untuk terjadinya penularan lebih tinggi dari pada kelompok usia muda sehingga menyebabkan lansia lebih banyak berada di rumah.

Beberapa faktor yang mempengaruhi tindakan lansia dalam pencegahan Covid 19 adalah pengetahuan dan sikap lansia tentang Covid 19. Pengetahuan yang tidak memadai dan sikap yang salah secara langsung dapat mempengaruhi praktik dalam tindakan pencegahan Covid 19. Hasil penelitian (7) tentang pengetahuan masyarakat tentang Covid 19 didapatkan pengetahuan cukup 59,6\%. Faktor yang penting dalam melakukan tindakan pencegahan adalah pengetahuan, dan sikap yang menggambarkan terbentuknya perilaku. Pengetahuan membentuk kepercayaan yang kemudian menjadi dasar bagi seseorang dalam mengambil keputusan dan menentukan perilaku terhadap objek tertentu (11).

Pada kondisi pandemi seperti ini lansia kadang sulit bisa memahami beberapa imbauan yang diberikan pemerintah terkait upaya menjaga diri agar tidak terpapar Covid 19. Lansia sangat memerlukan perlindungan dan akses terhadap informasi yang akurat terutama menjaga kesehatan fisik dan mental selama pandemik (10). Kehidupan lansia dapat terjaga apabila didukung dengan kesejahteraan dan kualitas hidup yang baik sehingga tetap sehat dan produktif di masa pandemi Covid 19. Tujuan penelitian adalah untuk mengetahui faktor yang paling berpengaruh terhadap tindakan pencegahan Covid 19 di RW 10 Kelurahan Labuh Baru barat Kecamatan Payung sekaki. 


\section{Metode Penelitian}

Jenis penelitian adalah kuantitatif dengan analitik observasional melalui pendekatan crossectional (12). Variabel yang digunakan dalam penelitian dalam penelitian ini yaitu tindakan pencegahan sebagai variabel dependen dan variabel independen sebagai faktor penyebab yaitu pengetahuan, sikap, usia, jenis kelamin, dan pendidikan.

Populasi dalam penelitian ini adalah seluruh lansia yang berada di RW 10. Penentuan teknik pengambilan sampel menggunakan purposive sampling dengan kriteria lansia usia lebih dari atau sama dengan 60 tahun, lansia tidak tirah baring, bisa berkomunikasi dengan baik, dan mau berpartisipasi dalam penelitian. Dari 143 jumlah populasi lansia yang menjadi sasaran dalam subjek penelitian, terdapat 104 orang lansia yang menjadi sampel dalam penelitian. Semua peserta menyetujui protokol penelitian dan memberikan persetujuan tertulis. Penelitian ini telah disetujui oleh Komite Etik Fakultas Kedokteran Universitas Riau dengan Nomor B/136/UN19.5.1.1.8/UEPKK/2020 dan memperhatikan prinsip-prinsip dalam proses penelitian.

Penelitian menggunakan kuesioner melalui wawancara langsung kepada responden dengan memperhatikan protokol kesehatan yaitu mencuci tangan, memakai masker, dan menjaga jarak. Kuesioner dibagi menjadi 3 bagian yaitu data demografi terdiri dari usia, jenis kelamin, dan pendidikan, bagian kedua kuesioner pengetahuan tentang Covid 19, bagian ketiga kuesioner tentang sikap, dan bagian terakhir kuesioner tentang tindakan pencegahan Covid 19.

Analisis bivariat dilakukan dengan menggunakan uji chi square untuk menentukan hubungan antara variabel pengetahuan, sikap terhadap variabel tindakan pencegahan Covid 19. Analisis regresi logistik multivariat digunakan untuk melihat variabel yang paling mempengaruhi tindakan pencegahan Covid 19 (13). Analisis data digunakan dengan menggunakan perangkat lunak program komputer

\section{Hasil Penelitian}

Tabel 1 menunjukkan bahwa tindakan pencegahan yang dilakukan lansia adalah lebih dari setengahnya melakukan tindakan pencegahan $(55,76 \%)$ yang terkait dengan memakai masker, mencuci tangan, dan menjaga jarak. Berdasarkan hasil karakteristik usia, sebagian besar lansia melakukan tindakan pencegahan yaitu lansia ideal 60-70 tahun $(78,2 \%)$ dan lansia berisiko 71 79 tahun $(29,2 \%)$, berdasarkan jenis kelamin sebagian besar lansia perempuan melakukan tindakan pencegahan $(70,3 \%)$ dan lansia laki-laki $(20,0 \%)$, dan berdasarkan tingkat pendidikan sebagian besar lansia melakukan tindakan pencegahan yaitu tingkat pendidikan menengah SMA $(84,3 \%)$ dan tingkat pendidikan rendah SD-SMP $(28,3 \%)$. Berdasarkan hasil dari dari instrumen penelitian menggunakan kuesioner pengetahuan, dan sikap tentang tindakan pencegahan Covid 19 sehingga didapatkan faktor yang mempengaruhi tindakan pencegahan Covid 19 ditinjau dari pengetahuan lansia lebih banyak yang melakukan tindakan pencegahan $(90,60 \%)$ pada tingkat pengetahuan yang tinggi, namun masih ada lansia yang tidak melakukan tindakan pencegahan $(9,4 \%)$. Untuk Sikap positif dalam pencegahan Covid 19 didapatkan lebih dari separuh $(67,2 \%)$ lansia melakukan tindakan pencegahan. Dari hasil iji chi square terdapat pengaruh antara usia $(\mathrm{p}=0,000)$, jenis kelamin $(\mathrm{p}=0,000)$, pendidikan $(\mathrm{p}-0,000)$, pengetahuan $(\mathrm{p}=0,000)$, sikap $(\mathrm{p}=0,000)$ terhadap tindakan pencegahan Covid 19.

Dalam analisis multivariat pada tabel 2 menunjukkan hasil akhir uji regresi logistik terhadap tindakan pencegahan Covid 19 sebagai varibel dependen didapatkan variabel pengetahuan $(p=0,000)$ memiliki pengaruh yang signifikan terhadap tindakan pencegahan. Berdasarkan hasil nilai OR menunjukkan variabel independen yang paling berpengaruh adalah pengetahuan dengan nilai $\mathrm{OR}=39,36$ yang artinya lansia dengan pengetahuan tinggi memiliki 39,36 kali untuk melakukan tindakan pencegahan Covid 19, dibanding lansia dengan pengetahuan rendah 
Tabel 1 Analisis bivariat faktor yang mempengaruhi tindakan pencegahan

Covid $19(n=104)$

\begin{tabular}{|c|c|c|c|c|c|c|c|c|c|}
\hline \multirow[t]{2}{*}{ Variabel } & \multicolumn{4}{|c|}{ Tindakan Pencegahan } & \multirow[t]{2}{*}{ Jumlah } & \multirow[t]{2}{*}{$\%$} & \multirow[t]{2}{*}{$p$} & \multirow[t]{2}{*}{ OR } & \multirow[t]{2}{*}{ CI 95\% } \\
\hline & Ya & $\%$ & Tidak & $\%$ & & & & & \\
\hline \multicolumn{10}{|l|}{ Usia } \\
\hline $60-69$ & 44 & 78,6 & 12 & 21,4 & 56 & 100 & 0,000 & 8,9 & $3,60-21,70$ \\
\hline $70-79$ & 14 & 29,2 & 34 & 70,8 & 48 & 100 & & & \\
\hline \multicolumn{10}{|l|}{ Jenis kelamin } \\
\hline Perempuan & 52 & 70,3 & 22 & 29,7 & 74 & 100 & 0,000 & 3,4 & $1,49-7,79$ \\
\hline Laki-laki & 6 & 20,0 & 24 & 80,0 & 30 & 100 & & & \\
\hline \multicolumn{10}{|l|}{ Pendidikan } \\
\hline SMA & 43 & 84,3 & 8 & 15,7 & 51 & 100 & 0,000 & 13,6 & $5,20-35,60$ \\
\hline SD-SMP & 15 & 28,3 & 38 & 71,7 & 53 & 100 & & & \\
\hline \multicolumn{10}{|l|}{ Pengetahuan } \\
\hline Tinggi & 48 & 90,6 & 5 & 9,4 & 53 & 100 & 0,000 & 39,3 & $12,40-124,5$ \\
\hline Rendah & 10 & 19,6 & 41 & 80,4 & 51 & 100 & & & \\
\hline \multicolumn{10}{|l|}{ Sikap } \\
\hline Positif & 43 & 67,2 & 21 & 32,8 & 64 & 100 & 0,006 & 3,4 & $1,49-7,79$ \\
\hline Negatif & 15 & 37,5 & 25 & 62,5 & 40 & 100 & & & \\
\hline
\end{tabular}

Tabel. 2 Hasil akhir pemodelan uji multivariat regresi logistik faktor yang mempengaruhi tindakan pencegahan Covid 19

\begin{tabular}{cccccc}
\hline Variabel & B & Wald & $p$ value & OR & $95 \%$ CI \\
\hline Pengetahuan & 3,673 & 39,73 & 0,000 & 39,36 & $12,44-124,5$ \\
\hline
\end{tabular}

\section{Diskusi}

Covid 19 tidak hanya menjadi persoalan kesehatan tapi juga menimbulkan berbagai aspek kehidupan masyarakat baik ekonomi, politik, keamanan, pertahanan, keamanan, sosial, dan budaya. Perubahan berbagai aspek turut mengubah perilaku masyarakat di seluruh dunia termasuk Indonesia. Meskipun Covid 19 menyerang seluruh usia tanpa melihat karakteristik, namun setiap individu memberikan respon yang berbeda sehingga menjadi penyebab kerentanan akibat Covid 19 pada kelompok karakteristik tertentu. Berdasarkan hasil penelitian ditemukan 53,84\% lansia berada pada rentang usia 60-69 tahun dan $(78,6 \%)$ lebih banyak melakukan tindakan pencegahan dibandingkan usia 70-79 tahun (29,2\%). Menurut Badan Pusat Statistik, dari seluruh lansia yang ada di Indonesia, lansia muda (60-69 tahun) jauh mendominasi dengan besaran yang mencapai $63,82 \%$, selanjutnya diikuti oleh lansia madya (70-79 tahun) sebesar 27,68\% dan lansia tua (> 80 tahun) sebesar 8,50\% (5).

Virus Corona sering menyebabkan infeksi berat dan kematian pada orang lanjut usia dibandingkan orang dewasa dan anak-anak. Kelompok lanjut usia yang rentan terhadap penyakit karena fungsi fisiologisnya berangsur-angsur akan berkurang termasuk sistem imun tubuh (14). Untuk jenis kelamin angka terbanyak berada pada perempuan yaitu $71,16 \%$ dan lebih banyak melakukan tindakan pencegahan $(70,3 \%)$ dibandingkan jenis kelamin laki-laki $(29,2 \%)$. Perempuan memiliki angka harapan hidup yang lebih panjang karena memiliki telomer (DNA) lebih panjang sehingga dapat melindungi DNA lebih lama. Dari segi genetika secara kromosom laki-laki memilki kromosom XY (berbeda) sedangkan perempuan XX (sama) dimana kromosom XX turut mendukung kerja sistem imun tubuh pada perempuan (15). Disamping itu kecenderungan laki-laki mengabaikan gangguan kesehatan yang dialami serta kondisi laki-laki yang banyak bekerja di luar sehingga rentan untuk terkena penyakit dan berisiko untuk terpapar virus yang mengakibatkan keterlambatan dalam memeriksakan diri ke 
sarana kesehatan ketika memiliki penyakit. Hal ini karena rendahnya penggunaan sarana kesehatan oleh kelompok laki-laki dibanding perempuan.

Menurut peneliti dari WHO, USA, dan China, laki-laki dianggap sebagai kelompok yang berisiko tinggi terkena virus Corona. Berdasarkan laporan dari Kota Wuhan data pasien yang dirawat menunjukkan lebih banyak laki-laki yang dirawat terinfeksi Covid 19 bahkan Chinese Center for Disease and Prevention menyatakan laki-laki yang terinfeksi Covid memiliki risiko kematian dua kali lebih tinggi dari pada wanita yang terinfeksi. Temuan ini juga sejalan dengan penelitian di Italia dimana tingkat kematian pada laku-laki jauh lebih tinggi dibandingkan perempuan. Hal ini diperkuat dari penelitian tim dokter RS Jinyintan Wuhan dan penelti Universitas Jiao Tong Sanghai yang mengatakan penyebabnya adalah karena berkurangnya kerentanan kaum wanita (16).

Dari segi tingkat pendidikan lansia didapatkan antara tingkat pendidikan tamat SMA $(49,04 \%)$ tidak jauh beda dengan tingkat pendidikan tamat SD-SMP (50,96\%). Tingkat pendidikan berbanding lurus dengan pengetahuan yang diterima. Namun pendidikan SMA lebih banyak yang melakukan tindakan pencegahan $(84,3 \%)$ dibandingkan pendidikan SD-SMP $(28,3 \%)$. Rendahnya pendidikan mempengaruhi partisipasi lansia dalam aktifitas fisik dan sosial dan penerimaan informasi sehingga mempengaruhi ketajaman daya ingat dan fungsi otak (17).

Dari wabah SARS pada tahun 2003 menunjukkan bahwa pengetahuan dan sikap terhadap penyakit menular dikaitkan dengan tingkat emosi panik diantara populasi, yang selanjutnya dapat mempersulit upaya untuk mencegah penyebaran penyakit (18). Adanya peningkatan kasus Covid 19 di Indonesia perlu diketahui pengetahuan, sikap dan tindakan masyarakat dalam pencegahan Covid 19. Berdasarkan Tabel 1 didapatkan tingkat pengetahuan tinggi sebanyak 50,96\%, rata-rata tingkat jawaban benar untuk setiap butir pertanyaan yang dijawab lansia 60,15\% dengan nilai tertinggi 86,5 dan nilai terendah 57,6. Untuk nilai tertinggi yang banyak dijawab benar yaitu soal pengetahuan tentang pencegahan Covid 19 dengan memakai masker, sedangkan jawaban soal yang banyak dijawab salah yaitu menahan diri untuk tidak menyentuh mata, hidung dan mulut. Hal ini dapat dipahami adanya jawaban yang benar yang dipilih lansia karena situasi epidemi yang serius dan banyaknya laporan berita Covid 19 tentang keadaan kesehatan masyarakat sehingga lansia akan secara aktif mempelajari pengetahuan tentang penyakit menular dari berbagai saluran informasi seperti televisi dan radio. Berdasarkan tabel tabel 1 didapatkan bahwa lansia yang berpengetahuan tinggi cenderung untuk melakukan tindakan pencegahan Covid 19 dibanding lansia dengan pengetahuan rendah. Hal ini sejalan dengan penelitian (19) bahwa lansia yang memiliki pengetahuan yang memadai tentang Covid 19 akan terlibat dalam tindakan yang proaktif dalam pencegahan Covid 19.

Penelitian di China Tiongkok tentang Covid 19 didapatkan dari keseluruhan item pertanyaan yang dijawab benar adalah 90\% (20). Penelitian di Urganda bahawa 70\% responden memiliki pengetahuan yang cukup tentang Covid 19 (21), sedangkan penelitian di Iran ditemukan 99\% responden memiliki tingkat pengetahuan yang sangat baik mengenai cara penularan penyakit (22). Pengetahuan tentang pencegahan utama Covid 19 yang ditanyakan yaitu memakai masker, termasuk menjaga kebersihan pernafasan (menutup mulut dan hidung saat batuk atau bersin), menjaga jarak sosial, dan menghindari kerumunan.

Penularan penyakit pada lansia kemungkinan disebabkan oleh pengetahuan dan kesadaran yang tidak memadai tentang praktik pencegahan. Berdasarkan Tabel 1 pengetahuan yang tidak memadai dapat secara langsung mempengaruhi tindakan yang rendah dalam pencegahan. Masih rendahnya persentase tingkat pengetahuan tinggi, persentase sikap positif dan persentase yang melakukan tindakan pencegahan Covid 19 hal ini bisa dimengerti karena lansia sangat terbatas dalam mengakses internet dan sumber informasi kesehatan yang saat ini lebih banyak disiarkan secara online mrlalui media sosial, sementara lansia memiliki keterbatasan dalam penggunaan gadget dan lebih mengandalkan media TV atau radio. Hal ini juga berhubungan dengan faktor usia dimana terjadinya penurunan kondisi kognitif, ekonomi dan keterbatasan dalam melakukan hubungan sosial dengan lingkungan sekitar. Temuan ini 
berguna bagi pembuat kebijakan kesehatan masyarakat dan petugas kesehatan untuk mengenali populasi sasaran pencegahan Covid 19 dan pendidikan kesehatan. Sesuai dengan Tabel 2 menunjukkan temuan lebih lanjut dalam intervensi pendidikan kesehatan akan lebih efektif jika menargetkan kelompok demografis tertentu, misalnya pengetahuan Covid 19 dapat meningkat jika program pendidikan kesehatan dirancang khusus untuk laki-laki dan dengan tingkat pendidikan rendah.

Berdasarkan hasil analisis multivariat melalui regresi logistik biner pada Tabel 2 didapatkan faktor usia, jenis kelamin, pendidikan, sikap tidak masuk dalam faktor yang mempengaruhi tindakan pencegahan setelah pemodelan analisis tahap akhir. Pemodelan tahap akhir didapatkan variabel pengetahuan merupakan faktor yang paling kuat pengaruhnya dalam tindakan pencegahan Covid 19 dengan OR=39,36. Pengetahuan tentang Covid 19 sangat penting bagi lansia. Lansia yang berpengetahuan akan membuka wawasan untuk menerima informasi yang positif sehingga lansia menjadi sehat, mandiri, aktif, dan produktif (23). Lansia yang berpengetahuan dapat memberdayakan diri untuk senantiasa mencari informasi. Tingkat pengetahuan berpengaruh dalam memberikan respon terhadap sesuatu yang datang dari luar. Intervensi yang efektif untuk peningkatan pengetahuan terhadap kerentanan yang dirasakan akan dapat mencegah lansia dari penyebaran penyebaran penyakit akibat Covid 19 (24). Adanya pengetahuan pada lansia dapat mempengaruhi kesehatan dan kemampuan untuk menyesuaikan diri terhadap lingkungan sekitar.

\section{Kesimpulan}

Hasil penelitian menunjukkan terdapat pengaruh antara usia, jenis kelamin, pendidikan, pengetahuan, dan sikap terhadap tindakan pencegahan. Dari hasil regresi logistik didapatkan pengetahuan merupakan faktor yang paling berpengaruh dalam tindakan pencegahan Covid 19 pada lansia, dimana lansia yang berpengetahuan tinggi akan melakukan tindakan pencegahan dibandingkan lansia yang berpengetahuan rendah. Oleh karena itu kepada lansia perlu diberikan pengetahuan tentang pencegahan Covid 19 dengan mematuhi protokol kesehatan sehingga lansia tetap bisa aktif dan produktif dalam menjalani kehidupan dimasa era tatanan baru Covid 19.

\section{Daftar Pustaka}

1. WHO. Co V I D - 19 Strategy Up Date. World Heal Organ. 2020;(April):18.

2. Davies NG, Klepac P, Liu Y, Prem K, Jit M, Pearson CAB, et al. Age-dependent effects in the transmission and control of COVID-19 epidemics. Nat Med. 2020;26(8):1205-11.

3. Hakim LN. Pelindungan Lanjut Usia Pada Masa Pandemi Covid-19. Perlindungan lanjut usia pada masa pandemi Covid-19. 2020;

4. Hidayati D. Profil Penduduk Terkonfirmasi Positif Covid-19 Dan Meninggal: Kasus Indonesia Dan Dki Jakarta. J Kependud Indones. 2020;2902:93.

5. Kemenkes. Analisis lansia di Indonesia. Pusat data dan imformasi kemenkes. 2019;

6. United Nations. Policy Brief: The Impact of COVID-19 on older persons. United Nations Sustain Dev Gr. 2020;(May):1-16.

7. Yousif W, Wahed A, Mamdouh E, Mona H, Ahmed I, Sayed N. Assessment of Knowledge , Attitudes, and Perception of Health Care Workers Regarding COVID - 19, A Cross Sectional Study from Egypt. J Community Health. 2020;(0123456789).

8. BNPB. Pedoman Perubahan Perilaku Penanganan COVID-19. satgas Covid19. 2020;60.

9. Wateraid. Hand hygiene for COVID-19 and beyond in India. 2020;

10. Barber SJ, Kim H. COVID-19 Worries and Behavior Changes in Older and Younger Men and Women. J Gerontol B Psychol Sci Soc Sci. 2021;76(2):e17-23.

11. Sembiring EE, Nena Meo ML. Pengetahuan dan Sikap Berhubungan dengan Resiko Tertular Covid-19 pada Masyarakat Sulawesi Utara. NERS J Keperawatan. 2020;16(2):75.

12. Creswel JW. Research Design: pendekatan kualitatif, kuantitatif, dan campuran. Yogyakarta: Pustaka Pelajar; 2016.

13. Ocaña-Riola R. The Use of Statistics in Health Sciences: Situation Analysis and Perspective. 
Stat Biosci. 2016;8(2):204-19.

14. Liu K, Chen Y, Lin R, Han K. Clinical features of COVID-19 in elderly patients: A comparison with young and middle-aged patients. J Infect. 2020;80(6):e14-8.

15. Sarvasti D. Pengaruh Gender dan Manifestasi Kardiovaskular Pada COVID-19. Indones J Cardiol. 2020;41(2).

16. Leung C. Risk factors for predicting mortality in elderly patients with COVID-19: A review of clinical data in China. Mech Ageing Dev. 2020;188(April):111255.

17. Morrow-Howell N, Galucia N, Swinford E. Recovering from the COVID-19 Pandemic: A Focus on Older Adults. J Aging Soc Policy. 2020;32(4-5):526-35.

18. UNFPA. UNFPA Global Technical Brief Implications of COVID-19 for Older Persons: Responding to the Pandemic. 2020;21.

19. Chen Y, Zhou R, Chen B, Chen H, Li Y, Chen Z, et al. Knowledge, perceived beliefs, and preventive behaviors related to covid-19 among Chinese older adults: Cross-sectional webbased survey. J Med Internet Res. 2020;22(12).

20. Zhong BL, Luo W, Li HM, Zhang QQ, Liu XG, Li WT, et al. Knowledge, attitudes, and practices towards COVID-19 among chinese residents during the rapid rise period of the COVID-19 outbreak: A quick online cross-sectional survey. Int J Biol Sci. 2020;16(10):1745-52.

21. Ssebuufu R, Sikakulya FK, Mambo SB, Wasingya L, Nganza SK, Ibrahim B, et al. Knowledge, Attitude, and Self-Reported Practice Toward Measures for Prevention of the Spread of COVID-19 Among Ugandans: A Nationwide Online Cross-Sectional Survey. Front Public Heal. 2020;8(December):1-9.

22. Moradzadeh R, Nazari J, Shamsi M, Amini S. Knowledge, Attitudes, and Practices Toward Coronavirus Disease 2019 in the Central Area of Iran: A Population-Based Study. Front Public Heal. 2020;8(December):1-7.

23. Ezalina E, Machmud R, Effendi N, Maputra Y. Effectiveness of the elderly caring model as an intervention to prevent the neglect of the elderly in the family. Open Access Maced J Med Sci. 2019;7(14):2365-70.

24. Zareipour MA, Ardakani MF, Moradali MR, Jadgal MS, Movahed E. Determinants of COVID19 Prevention Behavior in the Elderly in Urmia: Application of Health Belief Model. Open Access Maced J Med Sci. 2020;8(T1):646-50. 
UNIT ETIK PENELITIAN KEDOKTERAN DAN KESEHATAN ETICHAL REVIEW BOARD FOR MEDICINE \& HEALTH RESEARCH FAKULTAS KEDOKTERAN UNIVERSITAS RIAU

Jl. Diponegoro No. 1 Pekanbaru, Riau, Indonesia Kode Pos 28133

Telpon : +62(0761) 839264, Email: kajietik@gmail.com NOMOR KEPK : $1471032 P$

\section{KETERANGAN LOLOS KAJI ETIK \\ ETHICAL CLEARANCE}

No : B / 136 /UN19.5.1.1.8/UEPKK/2020

Protokol penelitian yang diusulkan oleh :

The research protocol proposed by

Peneliti utama

: DR. Ezalina, S.Kep. Ns. M.Kes

Principal Investigator

$\begin{array}{ll}\text { Anggota } & : \\ \text { Co-investigator } & \text { 1. DR. Deswinda, S.Kep. Ns. M.Kes } \\ \text { 2. Fitry Erlin. S.Kep. Ns. M.Kep }\end{array}$

Nama Institusi

: Sekolah Tinggi Ilmu Kesehatan (STIKes) Payung Negeri Pekanbaru

Name of the Institution

Dengan Judul

Title

PENGETAHUAN, SIKAP DAN TINDAKAN LANSIA DALAM PENCEGAHAN COVID 19 DI KELURAHAN LABUH BARU BARAT KECAMATAN PAYUNG SEKAKI KOTA PEKANBARU

Dinyatakan layak etik sesuai 7 (tujuh) Standar WHO 2011, yaitu 1) Nilai Sosial, 2) Nilai Ilmiah. 3) Pemerataan Beban dan Manfaat, 4) Risiko, 5) Bujukan/Eksploitasi, 6) Kerahasiaan dan Privacy, dan 7) Persetujuan Setelah Penjelasan, yang merujuk pada Pedoman CIOMS 2016. Hal ini seperti yang ditunjukkan oleh terpenuhinya indikator setiap standar.

Declared to be ethically appropriate in accordance to 7 (seven) WHO 2011 Standards, 1) Social Values, 2) Scientific Values, 3) Equitable Assessment and Benefits, 4) Risks, 5) Persuasion/Exploitation, 6) Confidentiality and Privacy, and 7) Informed Concent, referring to the 2016 CIOMS Guideline. This is as indicated by the fulfillment of the indicators of each standard.

Keterangan Lolos Kaji Etik ini berlaku selama kurun waktu tanggal 23 Oktober 2020 sampai dengan tanggal 23 Oktober 2021 dan dapat diperbaharui dengan pemberitahuan maksimal 30 hari sebelum masa berlaku habis.

This Ethical Clearance is Applicable from October 23, 2020 until October 23, 2021 and renewal must be submitted at least 30 days prior to expired date.

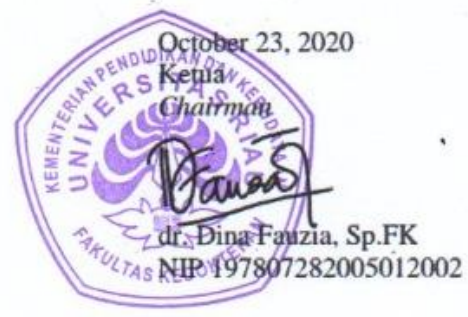

